\title{
MASONRY UNIT MANUFACTURING TECHNOLOGY USING POLYMERIC BINDER
}

\author{
Olena Levytska ${ }^{1,}$, Olena Dolzhenkova ${ }^{1}$, Oleksii Sichevyi ${ }^{1}$, Larysa Dorhanova $^{1}$
}

https://doi.org/10.23939/chcht14.01.088

\begin{abstract}
The paper discusses a problem of formation and search of efficient ways to recycle wastes generated by waste treatment plants, a proposed technology for their heat treatment and utilization of waste as a raw material component for the production of masonry units. Highdensity polyethylene is used as a binder.
\end{abstract}

Key words: recycling, sewage sludge, heating, melting, high-density polyethylene, forming.

\section{Introduction}

Waste management is well established in the developed countries and permits receiving useful products and energy from domestic household and industrial waste. At the same time, as people's needs increase, the production and consumption of plastic products have increased markedly, which leads to generation of large volumes of non-renewable wastes stored in organized or spontaneous landfills.

Therefore, the result of recycling polyethylene is useful products, including high-density polyethylene (HDPE) which is processed in a plastic lumber, trash receptacles, etc. [1]. In addition, polymers are used as catalysts, extractants, modifiers [2]. Also treated plastics are used in the cement matrix, and polymeric fibers can be used for strengthening cement [3].

HDPE is used as an aggregate for the production of concrete mixtures and the laboratory search discovered that the 28-day compressive strength of concrete containing 10 and $20 \mathrm{vol} \%$ of this type of plastic ranged from 22.997 to $26.617 \mathrm{MPa}$ [4]. However, when the specified content of HDPE exceeded $(20 \mathrm{vol} \%)$, the strength of concrete decreases, but the authors explain this not by the low strength of the plastic but by the low adhesion between it and the cement paste [4].

Oriyomi et al. [5] note not only about the possibility of using HDPE as an aggregate but also as a binder.

\footnotetext{
${ }^{1}$ Oles Honchar Dnipro National University,

72, Gagarina Av., 49000 Dnipro, Ukraine

هllevi@ukr.net

(c) Levytska O., Dolzhenkova O., Sichevyi O., Dorhanova L., 2020
}

Wastes generated by wastewater treatment plants resulting from the treatment of domestic and industrial wastewater are also the subject for recycling. Werle et al. [6] point to the distribution of storage, the use of such wastes in agriculture and for necessity of the development of thermal methods for utilization of sewage sludge in Poland.

However, microbiological contamination and unstable chemical composition of such wastes are an obstacle to their use as fertilizers. Thus the authors of [7, 8 ] note that the dry matter content of wastes generated by wastewater treatment plants include $1-3 \%$ of nitrogen, $1-$ $2 \%$ of phosphorus and $0.5-1.2 \%$ of potassium. In addition, $100 \mathrm{~g}$ of the dry matter of sludge contains 0.04 $0.22 \mathrm{~g}$ of manganese, $0.08-0.35 \mathrm{~g}$ of zinc and $0.02-0.35 \mathrm{~g}$ of copper. This fact is confirmed by chemical analyses of wastes from the Kamianske wastewater treatment plant which have high concentrations of $\mathrm{Sr}, \mathrm{Mn}$ and $\mathrm{Al}$ and the content of $\mathrm{Fe}$ exceeds the existing standards [9].

In addition, Franus et al. [10] suggest the use of sewage sludge in manufacturing a light aggregate in the production of building materials, indicating that the presence of a significant amount of heavy metals in the waste makes it an effective raw material.

Taking into account the foregoing, the authors of this paper set the goal to develop an optimal technology of sewage sludge utilization from waste treatment facilities in the production of construction materials.

\section{Experimental}

\subsection{Materials}

Sewage sludge from one of the Kamianske municipal wastewater treatment facilities (Ukraine) was used in the experiments. The specified wastes are formed using the following methods of treatment of industrial and domestic sewage:

- mechanical treatment, when the pollutants that are visible to the eye delay on lattice and in sand traps, and settle in the primary settling tank, 
- biological treatment, which involves detention and processing of organic compounds and compounds of heavy metals with the help of active silt consisting of destructive microorganisms, the separation of silt and water in a secondary settling tank.

Wastes from sand traps and the primary settling tanks and dewatered on the secondary settling tank excess of active silt arrive at the sludge maps - places of waste storage. The latest ones occupy hundreds of hectares of fertile lands in Ukraine and pollute the soils around. Therefore, the issue of utilization of large amounts of sewage sludge is an important task for the technologists and ecologists of the country.

\subsection{Preparation of the Samples}

The technology of sewage sludge and HDPE waste recycling includes the following stages: processing and mixing of wastes, heating of the waste mixture to the melting point of HDPE, forming and cooling. The products will be masonry units that can be used in industrial construction.

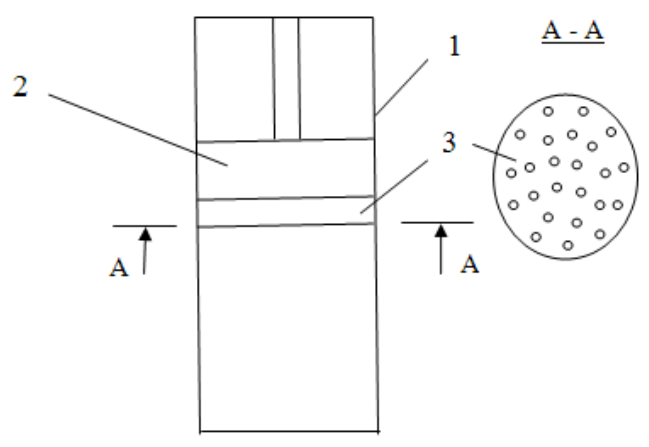

Fig. 1. Filter-press for dehydration of sewage sludge: filterpress housing (1); press (2) and screen (3)

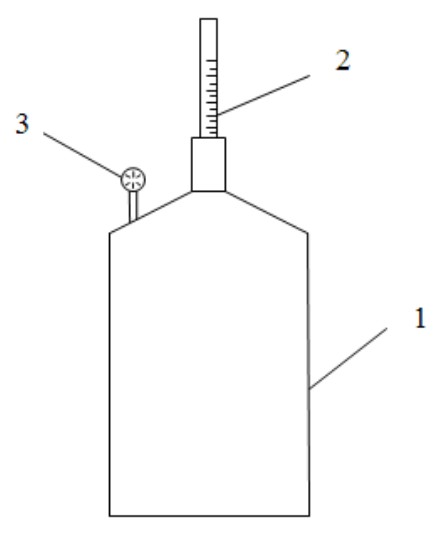

Fig. 3. Autoclave for heating sewage sludge and HDPE waste mixture: autoclave housing (1); thermometer (2) and barometer (3)
Using a filter-press made for the experiments (Fig. 1), wet sewage sludge (98\%) was dehydrated to $75 \%$ and its moisture content was lowered to $40 \%$ during heat drying.

HDPE used in the experiment was ground manually to particle size $2,4,6,8,10,12,14,16,18$ and $20 \mathrm{~mm}$. In the course of the experiments, dependence of the heating time of raw mixtures on the particle size of ground polyethylene was tested (Fig. 2). The results of the experiment showed that the smaller fractions of HDPE were melting faster. In particular, when reducing the size of HDPE fractions from 40 to $20 \mathrm{~mm}$, the heating time under the same conditions of supply and the amount of the heat will be reduced by almost half.

Decreasing the fineness of HDPE particles in the raw mixture increases its heating time, and, accordingly, the heat consumption, which is economically unprofitable. Therefore, it is better to use the smallest particles of HDPE.

The mixture of wastes was stirred for $1 \mathrm{~min}$, loaded into an autoclave (Fig. 3), heated to $408 \mathrm{~K}$, and then was stirred again for several minutes. The water vapor formed during the experiments escaped via the openings made on the device.

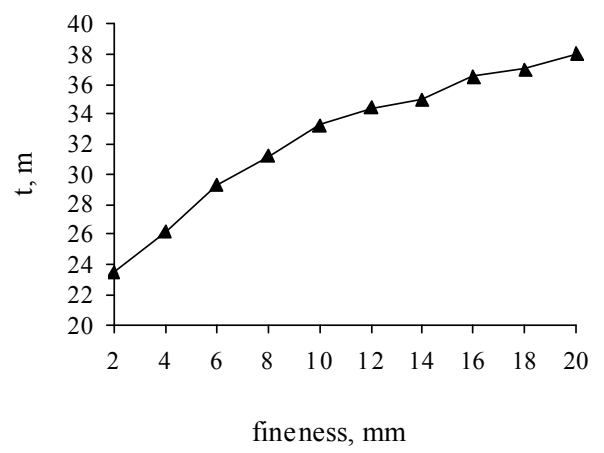

Fig. 2. Dependence of the heating time of raw mixture for making masonry units on the particle size of ground polyethylene

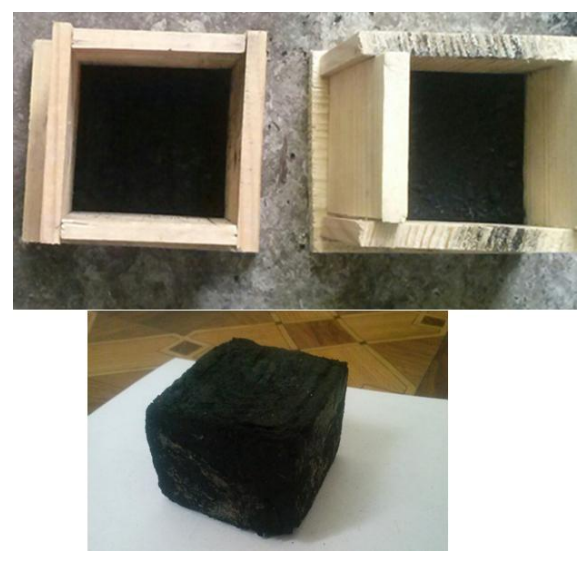

Fig. 4. Forming of samples of masonry units 
Autoclave operation parameters:

- pressure $202.65 \mathrm{kPa}$,

- the initial temperature $298 \mathrm{~K}$,

- the final temperature $408 \mathrm{~K}$,

- total heat consumption $516 \mathrm{~kJ} / \mathrm{kg}$.

- time for heating, softening and full melting of the mixture $24 \mathrm{~min}$.

The raw mixture ratio was determined experimentally. Thus an optimal appearance of the finished samples of construction products was reached with the volumetric ratio of sewage sludge to HDPE as (35-45):(55-65). Increasing the content of sewage sludge resulted in brittleness of the samples, and an increase in HDPE content is inexpedient from an economic point of view.

After being heated in an autoclave, the liquid hot mixture was poured into wooden cube moulds made for the experiments (Fig. 4). Samples of masonry units had a cuboid shape with a size of $70 \mathrm{~mm}$.

Masonry units, made from sewage sludges and HDPE wastes, were investigated for strength at compression and frost resistance, and their average density was determined.

\subsection{Analysis Methods}

The average density was determined according to [11]: the samples of the masonry units were dried to a constant weight, the mass and volume of the samples were determined and the average density $\rho_{s}, \mathrm{~kg} / \mathrm{m}^{3}$, as the ratio of the sample mass to its volume was calculated. Herewith three parallel samples were made and research results were averaged.

Frost resistance of samples of construction products was determined according to [11]: 20 samples with $70 \mathrm{~mm}$ faces were made, samples were filled with water and frozen and then were thawed. The frost resistance was estimated for the loss of the samples mass dried after thawing.

The strength at compression of building materials samples was determined according to [12]: samples of masonry units with $70 \mathrm{~mm}$ faces were prepared, samples were placed in the center of the bottom plate of the press, pressed with the top plate, reaching the growth of the load continuously and uniformly at a rate which provided an increase of the value of the calculated voltage in the masonry unit until its complete destruction within $(0.6 \pm 0.4) \mathrm{MPa} / \mathrm{s}$. The strength of the compression of the masonry unit sample was determined.

\section{Results and Discussion}

Taking into account the above, as well as the experimental laboratory studies of wastes which are shown in Tables 1 and 2 [9], used by the authors in this paper, it should be noted about the presence of metal compounds in the sewage sludge. The largest content is made up of iron and aluminum compounds. In addition, sewage sludge may contain pathogenic microorganisms. Therefore, the usage of thermal processing methods is necessary.

Table 1

The content of chemicals in the waste products of the right-bank sewage treatment facilities of the city of Kamyanske, g/kg [9]

\begin{tabular}{|l|l|l|l|l|l|}
\hline $\mathrm{P}_{2} \mathrm{O}_{5}$ & $\mathrm{CaO}$ & $\mathrm{MgO}$ & $\mathrm{K}_{2} \mathrm{O}$ & $\mathrm{Na}_{2} \mathrm{O}$ & $\mathrm{N}_{\text {total }}$ \\
\hline 22.5 & 75 & 7.5 & 5 & 1.5 & 28 \\
\hline
\end{tabular}

Table 2

The content of metals in the waste products of the right-bank sewage treatment facilities of Kamyanske, mg/kg [9]

\begin{tabular}{|c|c|c|c|c|c|}
\hline Metal & Actual content & Standarts for the waste [15] & Metal & Actual content & Standarts for the waste [15] \\
\hline $\mathrm{Ba}$ & 1000 & $\mathrm{n} / \mathrm{d}$ & $\mathrm{Sr}$ & 150 & 300 \\
\hline $\mathrm{Cr}$ & 100 & 750 & $\mathrm{Mn}$ & 1000 & 2000 \\
\hline $\mathrm{Pb}$ & 70 & 750 & $\mathrm{Bi}$ & 2 & $\mathrm{n} / \mathrm{d}$ \\
\hline $\mathrm{Sn}$ & 5 & $\mathrm{n} / \mathrm{d}$ & $\mathrm{Nb}$ & 10 & $\mathrm{n} / \mathrm{d}$ \\
\hline $\mathrm{Ga}$ & 10 & $\mathrm{n} / \mathrm{d}$ & $\mathrm{Ag}$ & 3 & $\mathrm{n} / \mathrm{d}$ \\
\hline $\mathrm{Ni}$ & 30 & 200 & $\mathrm{Al}$ & $10^{5}$ & $\mathrm{n} / \mathrm{d}$ \\
\hline $\mathrm{Zn}$ & 300 & 2500 & $\mathrm{Fe}$ & $10^{5}$ & $2.5 \cdot 10^{4}$ \\
\hline $\mathrm{Cd}$ & 3 & 30 & $\mathrm{Cu}$ & 50 & 1500 \\
\hline $\mathrm{Co}$ & 7 & 100 & $\mathrm{~V}$ & 20 & $\mathrm{n} / \mathrm{d}$ \\
\hline $\mathrm{Ti}$ & 500 & $\mathrm{n} / \mathrm{d}$ & $\mathrm{Mo}$ & 2 & $\mathrm{n} / \mathrm{d}$ \\
\hline
\end{tabular}

Note: $\mathrm{n} / \mathrm{d}$ - the value was not determined 
The greater part of the cement clinker on the chemical composition is calcium oxide. Also, cement clinkers have in their composition compounds of magnesium (alite), potassium and sodium (aluminate phase). Phosphates and nitrogen compounds are nontypical components of building materials. Phosphates significantly reduce the heat of portland cement [13]. Nitrates of potassium, sodium and ammonium are slowing down the periods of cement stubbing [14].

Wastewater treatment plants, depending on the type of industrial enterprises that send their wastewater to the wastewater treatment plant, can contain large amounts of metals. Considering that in the eastern region of Ukraine there are chemical, metallurgical, machinebuilding and mining enterprises, wastes from the treatment facilities contain compounds of various metals, but the established standarts are exceeded by the content of the iron compounds. At the same time, iron-containing materials are used in construction and do not pose a threat to people and the environment.

HDPE wastes were also examined. It was taken into account that HDPE, when heated above 403-413 K, can pollute the atmosphere with such volatile pollutants as formaldehyde, organic acids, carbon monoxide, etc.

The technology of making masonry units is based on the property of HDPE to melt at relatively low temperatures and stiffen when these temperatures are dropping. All the components of the future building materials are heated simultaneously, which contributes to the reducing of the cost of energy resources for the process. After mixing and heating, small fractions of the sewage sludge blend with the melted masses of HDPE. Depending on the sewage sludge and HDPE waste ratio, pasty suspensions are formed and are used as a raw material for making masonry units.
A flow diagram illustrating the masonry unit production process is shown in Fig. 5.

The primary task in preparing raw materials components is the dewatering of sewage sludge. For this purpose mechanical methods of o sewage sludge processing is being introduced at the treatment plants today. The most popular and economically feasible among them are filter presses and centrifuges. However, centrifuges are more energy-consuming than filter presses. Therefore, the latest are recommended for using.

Sewage sludge (1) is dehydrated in the filter-press (4) and, together with ground HDPE wastes is fed to the mixer (7). The mixture (8) then is loaded into the melting and heating apparatus (9), heated to a melting point of HDPE and stirred again. The melted mixture of sewage sludge and HDPE (10) is poured into the vibropress (11) and formed into masonry units. Equipment for the formation of masonry units should be made from materials which are resistant to high temperatures. Standart size of masonry units which can be produced using this technology is 390:190:188 mm.

For the manufacture of masonry units from wastes, the raw material is purchased partly, which is the cost of its acquisition, and is partially recycled - when the wastemaking enterprise pays the money for its utilization. Thus, an enterprise that produces construction products receives profits. In this case, wastes from treatment plants will bring profit, but the wastes of polyethylene today are sold as raw materials.

To determine qualitative characteristics of the masonry units, 3 parallel studies were conducted and their results were averaged. The obtained values of qualitative characteristics of masonry units are shown in the comparison with standard values and are given in Table 3 .
Fig. 5. Flow diagram of the masonry unit production: sewage sludge containing about $98 \%$ water (1); wastewater that returns for treatment (2); dehydrated sewage sludge (3); filter-press (4); mechanical grinder (5); ground HDPE wastes (6); mixer (7); mixture of sewage sludge and ground HDPE wastes (8); melting and heating apparatus (9); mixture of melted HDPE and heated sewage wastes (10); vibropress (11)

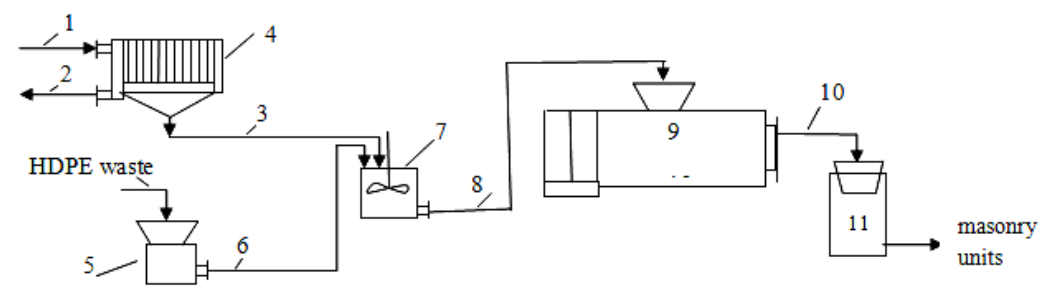

Table 3

Qualitative characteristics of masonry units made using sewage sludge

\begin{tabular}{|c|c|c|c|}
\hline \multirow{2}{*}{ Qualitative characteristic } & Units with sewage sludge:HDPE ratio, wt/wt (v/v in brackets) & \multirow{2}{*}{ Standard [16] } \\
\cline { 2 - 4 } & $35: 65(22: 78)$ & 45:55 (28:72) & - \\
\hline Colour & black & black & - \\
\hline Density, $\mathrm{kg} / \mathrm{m}^{3}$ & 1224 & 7230 & $2.5-15.0$ \\
\hline Strength, $\mathrm{MPa}$ & 7.4 & F30 & F15-100 \\
\hline Frost resistance & F30 & & -5 \\
\hline
\end{tabular}


Thus, by their compressive strength and frost resistance, the samples of construction products produced during the experiments comply with the applicable regulatory requirements and are recommended for use in industrial construction. Masonry units are recommended for laying walls of industrial installations, warehouses, storage chambers, arrangement of waste storage places, construction of garages and other buildings, which do not provide for the permanent residence of people, animals and the location of food.

Expenditure on raw materials for production, electricity and water, wages, rent of land for the production and storage of raw materials and products, transportation of raw materials, laboratory researches of quality of raw materials and manufactured products may be attributed to the current expenses, which will be spent on the implementation of masonry units manufacturing technologies.

\section{Conclusions}

An increase in the comprehensive strength of masonry units due to addition of sewage sludge is expected because it contains such compounds of highstrength metals as $\mathrm{Al}$ having a strength up to $88 \mathrm{MPa}$ [17] and Fe having a strength up to $210 \mathrm{MPa}$ [18]. Thus the technology of masonry unit production using the sewage sludge and HDPE wastes makes it posssible not only to dispose of generated wastes, but also to receive competitive building products - masonry units - which are recommended for use in industrial construction.

\section{References}

[1] Napier T.: Construction Waste Management. https://www.wbdg.org/resources/construction-waste-management [2] Khodakarami M., Alagha L.: Polym-Plast. Technol., 2017, 56, 2019. https://doi.org/10.1080/03602559.2017.1298800

[3] Cousins K.: Polymers in Building and Construction. ChemTec Publishing, 2002.

[4] Rahim N., Salehuddin S., Ibrahim N. et al.: Adv. Mater. Res., 2013, 701, 265. doi:10.4028/www.scientific.net/AMR.701.265
¡5] Okeyinka O., Oloke D., Khatib J.: Int. J. Civil Environ. Eng., 2015, 9, 1570.

[6] Werle S., Wilk R.: Renew. Energ., 2010, 35, 1914.

https://doi.org/10.1016/j.renene.2010.01.019

[7] Shevchuk V., Chebot $\square$ ko K., Razgulyayev V.: Biotekhnolohiya

Oderzhannya Orhanomineral $\square$ nykh Dobryv iz Vtorynnoyi

Syrovyny. EkoBioTekh, Kyiv 2001.

[8] Likhachova A., Beskostaya L., Shybeka L.: Tezy dopovidey Mizhnarodnoyi naukovo-tekhnichnoyi konferentsiyi "Suchasni problemy nano-, enerho- ta resursozberihayuchykh i ekolohichno oriyentovanykh khimichnykh tekhnolohiy". Ukraine, Kharkiv 2010, 310.

[9] Levytskaya Ye.: Visnyk Nats. Tekhn. Univ. “KPI”, 2012, 63, 67. [10] Franus M., Barnat-Hunek D., Wdowin M.: Environ. Monit. Assess., 2016, 188, 10. https://doi.org/10.1007/s10661-015-5010-8

[11] Metody vyznachennya vodopohlynannya, hustyny $\mathrm{i}$ morozostiykosti budivel $\square$ nykh materialiv i vyrobiv. DSTU B V.2.7-42-97, Kyiv, Derkommistobuduvannya Ukrainy, 1997, 19. [12] Materialy stinovi. Metody vyznachennya hranyts $\square$ mitsnosti pry stysku i zhyni. DSTU B V.2.7-248:2011, Kyiv, Minrehion Ukrainy, 2012, 18.

[13] Dvorkin L., Dvorkin O.: Stroitelnyie Vyazhuschie Materialy. Infra-Inzheneriya, Moskva 2011.

[14] http://chemtech-bayern.com.ua/uk/statti/168.

[15] http://search.ligazakon.ua/1_doc2.nsf/link1/REG6691.html

[16] http://online.budstandart.com/ua/catalog/docpage?id_doc $=25433$

[17] http://metmk.com.ua/113spr_alum.php

[18] https://uk.wikipedia.org/wiki/Zalizo

Received: May 14, 2018 / Revised: May 29, 2018 / Accepted: October 2018

\section{ТЕХНОЛОГІЯ ВИГОТОВЛЕННЯ СТІНОВИХ КАМЕНІВ ІЗ ЗАСТОСУВАННЯМ ПОЛІМЕРНОГО ЗВ'ЯЗУЮЧОГО}

Анотація. Показана проблема утворення та пошуку шляхів утилізащії відходів очисних споруд та запропонована технологія їх термічного оброблення та використання як сировинний компонент при виготовленні стінових каменів. Як зв'язуюче запропоновано використовувати поліетилен низького тиску.

Ключові слова: утилізачія, відходи очисних споруд, нагрівання, розплавлення, поліетилен низького тиску, формування. 